\title{
Time-resolved black carbon aerosol vertical distribution measurements using a 356-m meteorological tower in Shenzhen
}

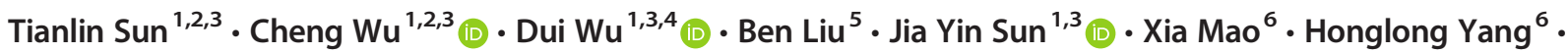 \\ Tao Deng ${ }^{4} \cdot$. Lang Song ${ }^{1,3} \cdot{\text { Mei } \mathrm{Li}^{1,3} \cdot \text { Yong Jie } \mathrm{Li}^{5} \text { (D) } \cdot \text { Zhen Zhou }}^{1,3}$
}

Received: 12 June 2019 / Accepted: 24 February 2020 / Published online: 6 March 2020

(C) The Author(s) 2020

\begin{abstract}
Black carbon (BC) is an essential climate forcer in the atmosphere. Large uncertainties remain in BC's radiative forcing estimation by models, partially due to the limited measurements of $\mathrm{BC}$ vertical distributions near the surface layer. We conducted time-resolved vertical profiling of BC using a 356-m meteorological tower in Shenzhen, China. Five micro-aethalometers were deployed at different heights $(2,50,100,200$, and $350 \mathrm{~m})$ to explore the temporal dynamics of BC vertical profile in the highly urbanized areas. During the observation period (December 6-15, 2017), the average equivalent BC (eBC) concentrations were $6.6 \pm 3.6,5.4 \pm 3.3,5.9 \pm 2.8,5.2 \pm 1.8$, and $4.9 \pm 1.4 \mu \mathrm{g} \mathrm{m}{ }^{-3}$, from 2 to $350 \mathrm{~m}$, respectively. eBC temporal variations at different heights were well correlated. $\mathrm{eBC}$ concentrations generally decreased with height. At all five heights, eBC diurnal variations exhibited a bimodal pattern, with peaks appearing at 09:00-10:00 and 19:00-21:00. The magnitudes of these diurnal peaks decreased with height, and the decrease was more pronounced for the evening peak. eBC episodes were largely initiated by low wind speeds, implying that wind speed played a key role in the observed eBC concentrations. eBC wind-rose analysis suggested that elevated $\mathrm{eBC}$ events at different heights originate from different directions, which suggested contributions from local primary emission plumes. Air masses from central China exhibited much higher eBC levels than the other three backward trajectory clusters found herein. The absorption Ångström exponent $\left(\mathrm{AAE}_{375-880}\right)$ showed clear diurnal variations at $350 \mathrm{~m}$ and increased slightly with height.
\end{abstract}

Keywords Meteorological tower $\cdot$ Micro-aethalometer $\cdot$ Black carbon aerosol $\cdot$ Vertical distribution

\section{Introduction}

Black carbon (BC) is an important atmospheric aerosol component and is produced by the incomplete combustion of

Electronic supplementary material The online version of this article (https://doi.org/10.1007/s00704-020-03168-6) contains supplementary material, which is available to authorized users.

\footnotetext{
Cheng Wu

wucheng.vip@foxmail.com

$\triangle$ Dui Wu

wudui.vip@foxmail.com

$\bowtie$ Zhen Zhou

zhouzhen@gig.ac.cn

1 Institute of Mass Spectrometry and Atmospheric Environment, Jinan University, Guangzhou 510632, China

2 State Key Laboratory of Organic Geochemistry, Guangzhou Institute of Geochemistry, Chinese Academy of Sciences,

Guangzhou 510640, China
}

carbonaceous materials (Bond and Bergstrom 2006). Recent industrial development and rapid increases in world population have led to the consumption of large amounts of fossil fuels, which, together with anthropogenic biomass burning

3 Guangdong Provincial Engineering Research Center for On-line Source Apportionment System of Air Pollution, Guangzhou 510632, China

4 Institute of Tropical and Marine Meteorology, CMA, Guangzhou 510080, China

5 Department of Civil and Environmental Engineering, Faculty of Science and Technology, University of Macau, Taipa, Macau, China

6 Shenzhen Meteorological Bureau, CMA, Shenzhen 518040, China 
and automobile exhaust emissions, have resulted in a significant increase in the concentration of $\mathrm{BC}$ in the atmosphere (Ruppel et al. 2014). BC aerosol can affect the climate by modifying the radiative properties of the atmosphere (Reddy and Boucher 2007). BC may be the third most important component of global warming after $\mathrm{CO}_{2}$ and $\mathrm{CH}_{4}$ (Bond et al. 2013). The optical absorption properties of $\mathrm{BC}$ can greatly reduce atmospheric visibility (Moosmüller et al. 2009). BC can also carry toxic substances and heavy metals into the body and induces respiratory and cardiovascular problems (Highwood and Kinnersley 2006; Borm et al. 2004). Because BC can have substantial impacts on global climate change, regional ambient air quality, and human health, BC has become an increasingly important field of atmospheric research in recent years (Bond et al. 2013). In response, numerous counties have established national-wide $\mathrm{BC}$ monitoring networks (Kirchstetter et al. 2017; Kutzner et al. 2018; Zhang et al. 2008, 2012). However, most existing BC studies have been ground-based. Modeling studies suggested that substantial uncertainties of $\mathrm{BC}$ radiative forcing were arise from limited measurement of BC vertical profiles (Samset et al. 2013; Zarzycki and Bond 2010). As a result, field measurements of $\mathrm{BC}$ vertical profiles are useful for reducing the uncertainties of $\mathrm{BC}$ radiative forcing in climate models.

In China, ground-based $\mathrm{BC}$ observations had been performed in various locations (Zhang et al. 2008; He et al. 2009b; Wu et al. 2009, 2012; Zhuang et al. 2014, 2015; Chen et al. 2016; Ji et al. 2017). Globally, ground-based BC measurements have been made from polar regions (Sharma et al. 2004) to urban areas (Chen et al. 2016). However, measurements of $\mathrm{BC}$ vertical distributions remain limited. Wu et al. (2009) conducted parallel BC measurements at the foot and top of a hill using two aethalometers. Aircraft-based measurement is a useful tool for studying $\mathrm{BC}$ vertical profiles. For example, Schwarz et al. (2008) conducted aircraft-based BC measurements in Costa Rica. Vaishya et al. (2018) reported vertically resolved light absorption profiles at Indo-Gangetic Plain (IGP) using aircraft measurements and found significant atmospheric warming induced by BC. Wang et al. (2018a) found a decreasing trend of light absorption with height within 0-3 km, and the light absorption vertical profiles were influenced by the evolution of a boundary layer. The influence of boundary layer height on $\mathrm{BC}$ vertical profiles was also observed by aircraft measurements in India (Safai et al. 2012) and Nepal (Singh et al. 2019). In the arctic region, BC was found to be more abundant in the upper polar dome (Willis et al. 2019). Aircraft measurements in the Yangtze River Delta found increased organic carbon to elemental carbon ratio with height (Ren et al. 2018). However, the high cost of aircraft measurements limits its applications in field studies. Besides aircraft, balloon sounding was also useful for probing the $\mathrm{BC}$ vertical distribution, especially for height below $1000 \mathrm{~m}$, whose range was usually not covered by aircraft measurements due to the takeoff and landing process. Ran et al. (2016) explored the variability of BC vertical profile measurements at the North China Plain using a tethered balloon. (Li et al. 2015) studied BC profile variations in Shanghai. Lu et al. (2019) studied BC vertical profiles in the boundary layer in the Yangtze River Delta. Tethered balloon-based vertical profiling of BC was also been reported in India (Babu et al. 2011; Bisht et al. 2016; Mishra et al. 2018), New Zealand (Trompetter et al. 2013), Italy (Ferrero et al. 2011; Ferrero et al. 2014), and Arctic region (Ferrero et al. 2016; Markowicz et al. 2017). In recent years, unmanned aerial vehicles (UAV) were also applied for BC vertical profiling. UAV-based BC vertical profiling studies had been conducted in the Yellow Sea (Ramana et al. 2010), Indian Ocean (Corrigan et al. 2008), Yangtze River Delta (Li et al. 2018), and Pearl River Delta (Liu et al. 2020). UAV provides more flexibility in field deployments, but UAV is limited in payload capacity and temporal coverage. Nevertheless, vertical BC profile measurements, and especially time-resolved measurements, remain limited. In comparison, the meteorological mast can provide continues measurements at different heights. Xie et al. (2019) studied the light absorption vertical profile in Beijing during winter using the Beijing meteorological mast. Wang et al. (2018b) found that constant BC profiles accounted for $37 \%$ of all profiles during winter haze episodes in Beijing. Recent studies have suggested that the interactions between $\mathrm{BC}$ and the boundary layer can cause a "dome effect" that leads to air pollutant accumulation (Wendisch et al. 2008; Ding et al. 2016). Considering the limited number of existing studies on $\mathrm{BC}$ vertical distributions and the importance of $\mathrm{BC}$ vertical profile on evaluating BC's climate effect, there is a strong need for time-resolved $\mathrm{BC}$ vertical distribution measurements in order to better characterize the environmental effects of BC.

Shenzhen, which is located in the southern part of Guangdong Province (in southern China) on the eastern bank of the Pearl River Estuary, is an important international gateway and home to numerous high-tech companies. Shenzhen ranked 11th cleanest of 74 major Chinese cities in terms of $\mathrm{PM}_{2.5}$ in December 2017, with a monthly average $\mathrm{PM}_{2.5}$ concentration of $46 \mu \mathrm{g} \mathrm{m}^{-3}$ (CNEMC 2018). The air quality improvement of Shenzhen in recent years may be partially attributed to the active pollution control measures implemented by the local government. For example, the number of public electric buses in Shenzhen has surpassed the total number of electric buses in major metropolitan areas in the USA, and 90\% taxis in Shenzhen have been electrified (Keegan 2018). As a coastal city, Shenzhen is an ideal location to examine the characteristics of $\mathrm{BC}$ from local vehicular emissions. Thus, this study aims to characterize the temporal dynamics of $\mathrm{BC}$ vertical distributions near the surface layer in the highly urbanized areas. Field measurements were conducted at the 356$\mathrm{m}$ meteorological tower in Shiyan, Shenzhen, on December 
6-15, 2017. Equivalent BC (eBC) concentrations were measured at different heights, and the vertical distributions were analyzed in combination with meteorological data.

\section{Field measurements}

\subsection{Observation site}

The observation site location is shown in Fig. 1. The Shenzhen meteorological tower (SZMT) is located in a protected area in the Tiegang Reservoir, Bao'an District, Shenzhen, and surrounded by orchards. Although the area within the reservoir was covered by vegetation, the areas beyond the reservoir had been fully urbanized as shown in Fig. 1. An expressway is located near the site, and expressway vehicle emissions are one of the sources affecting the observations. Open burning of straw and trash was also observed within the reservoir area during the observation period occasionally, which may have affected the measurement results. With a height of $356 \mathrm{~m}$, the SZMT is the tallest meteorological mast tower in Asia and the second tallest in the world. The SZMT platform was designed to enable integrated vertical measurements of meteorological and environmental parameters (Li et al. 2020).

\subsection{The advantage of meteorological masts over other tower types}

TV towers have difficulties for meteorological and pollutant measurements (Deng et al. 2015), primarily because the surrounding airflow may be disturbed by the solid bulk cross section of the tower structure. In contrast, meteorological masts are much smaller and feature a hollow structure, which is much more conducive to ventilation and minimizes airflow disturbances. In addition, the meteorological mast cross section is identical at all heights, enabling uniform flow through the mast at all altitudes. These features ensure consistent measurement accuracy at different heights. Meteorological masts also have an advantage over other approaches, including unmanned aerial vehicles (UAVs) (Liu et al. 2020; Li et al. 2018; Pikridas et al. 2019), tethered balloons (Ferrero et al. 2011; Li et al. 2015; Ran et al. 2016; Lu et al. 2019), and airships (Rosati et al. 2016) in that they can support continuous time-resolved measurements at different heights $(\mathrm{He}$ et al. 2009a). For example, Wu et al. (2015) conducted $\mathrm{PM}_{2.5}$ sampling at four heights $(10,40,120$, and $220 \mathrm{~m})$ using a meteorological mast in Tianjin, finding that mass percentage of $\mathrm{SO}_{4}{ }^{2-}, \mathrm{NO}_{3}{ }^{-}$, and $\mathrm{OC}$ increased with height. The $325-\mathrm{m}$ meteorological tower in Beijing has been used to study the vertical distribution of $\mathrm{PM}_{2.5}$ (Sun et al. 2013; Wang et al. 2018b; Zhou et al. 2018), and the Amazon Tall Tower Observatory (ATTO) has proven useful for studying atmospheric composition and physical properties (Andreae et al. 2015). Finally, long-term studies have been undertaken using the Zotino Tall Tower Observatory (ZOTTO) in Central Siberia (Chi et al. 2013).

\subsection{Instrumentation and deployment}

Two types of micro aethalometers were used in this study: the MA200 (AethLabs, CA, USA), which provides eBC measurements at five wavelengths, and the AE51 (AethLabs, CA, USA), which reports eBC at $880 \mathrm{~nm}$ only. Microaethalometers employ the same principle as rack-mount aethalometers (Hansen et al. 1984). Both MA200 and AE51 were operated at a flow rate of $150 \mathrm{ml} / \mathrm{min}$ for sampling. The AE51 collects samples on a quartz filter strip, which requires

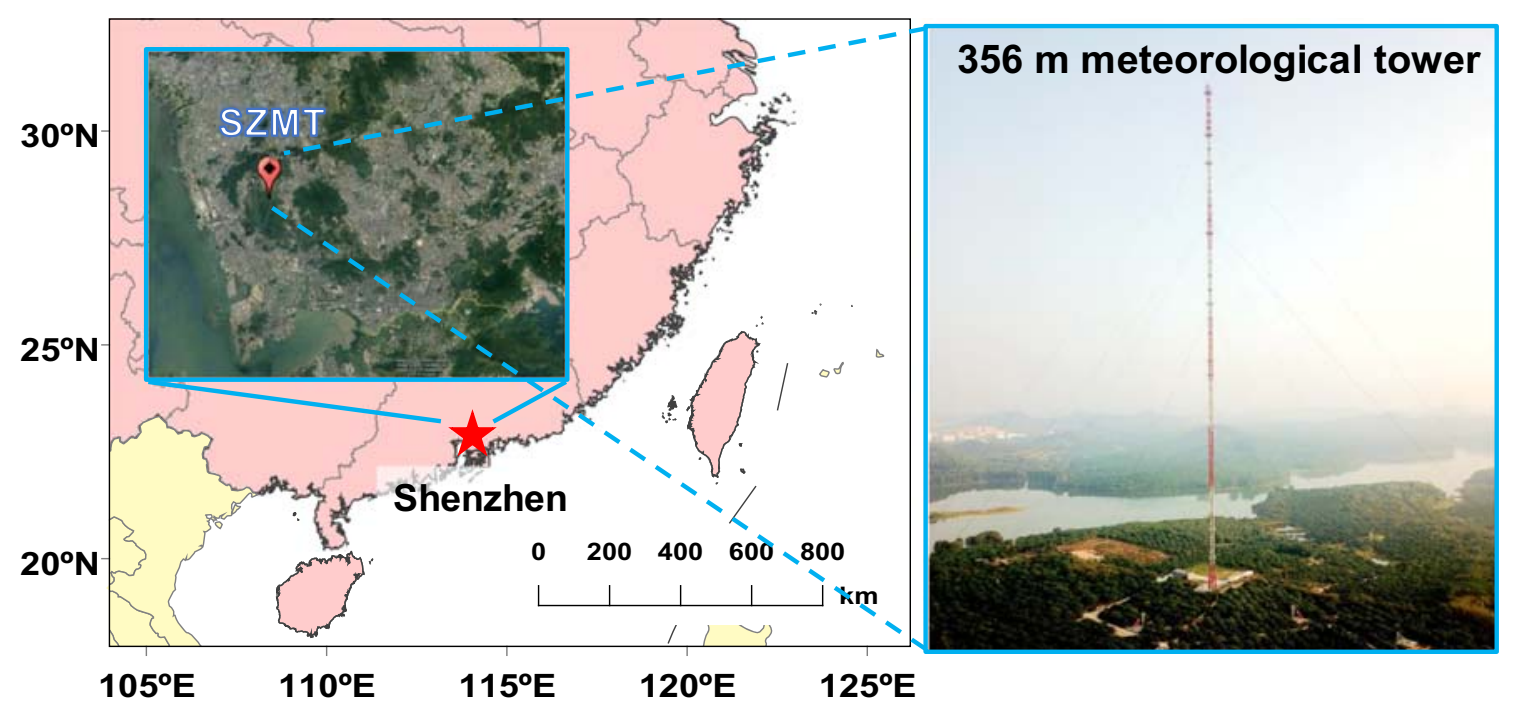

Fig. 1 Map of the sampling site and photo of the 356-m Shenzhen meteorological tower (SZMT) 
Fig. 2 eBC concentration frequency distributions at the five sampling heights as shown in a-e. The solid line red represents the lognormal distribution function fitted curve, and $\mathrm{N}$ represents the amount of data. Box plot of eBC at different heights is shown in $\mathbf{f}$
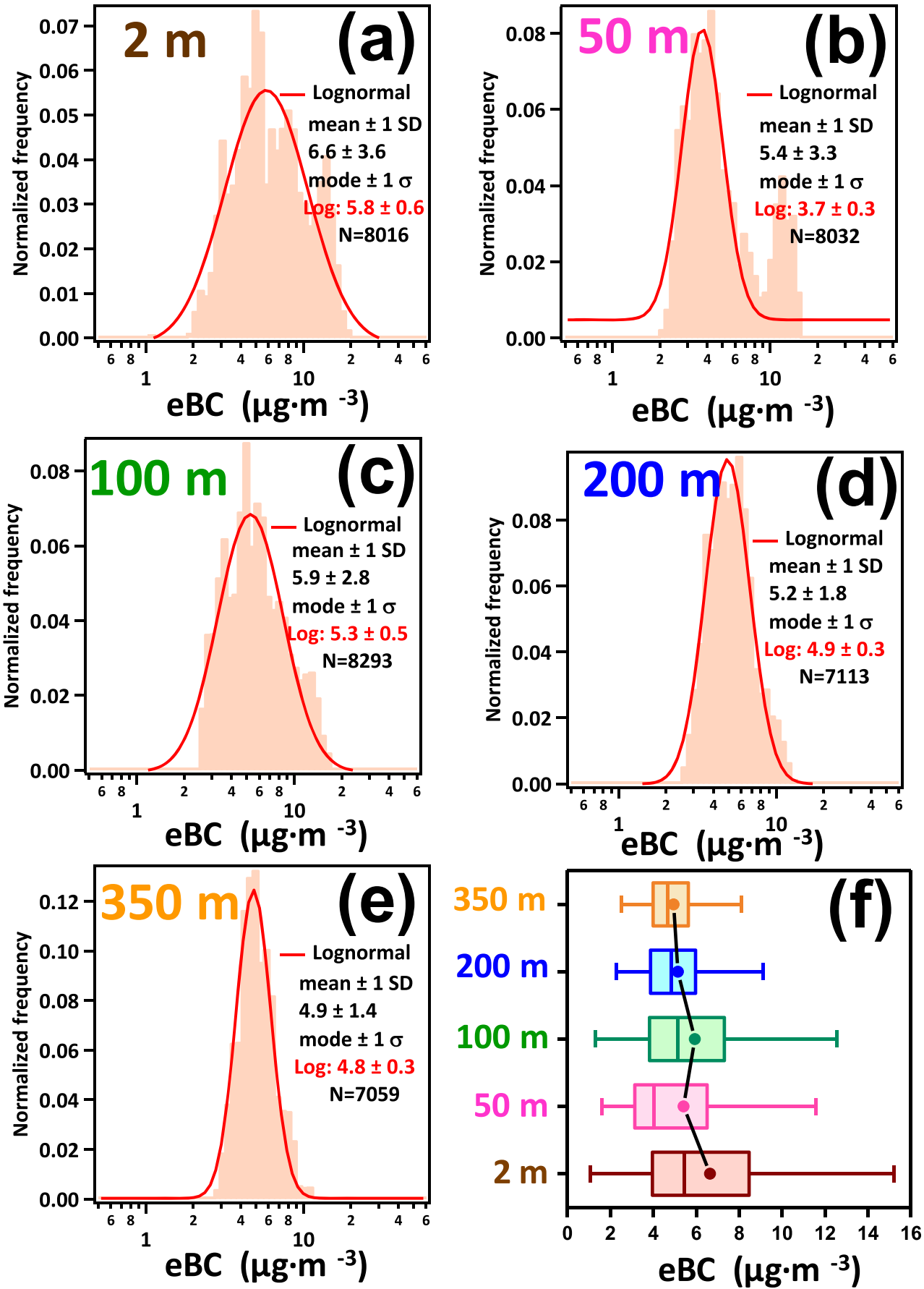

manual replacement once the light attenuation (ATN) value exceeds 100 (unitless).

The MA200 uses a filter cartridge with 15 sampling spots, making it more suitable for multiple-day sampling. The filter advancing threshold for ATN was 100 for MA200 in this study. MA200 equipped with 5 LED light sources, covering the wavelength from 375 to $880 \mathrm{~nm}$. That enables the determination of wavelength dependency of the samples. The meteorological tower has 13 vertically distributed observation platforms (at 10, 20, 40, 50, 80, 100, 150, 160, 200, 250,
300,320 , and $350 \mathrm{~m}$ ); the observations for this study were performed at ground level $(2 \mathrm{~m})$ and 50, 100, 200, and $350 \mathrm{~m}$ (Fig. S1). Three AE51 instruments (placed at 2, 50 , and $100 \mathrm{~m}$ ), and two MA200 instruments (placed at 200 and $350 \mathrm{~m}$ ) were used, and $\mathrm{eBC}$ data were obtained at a total of five altitudes. Due to a power supply interruption, eBC data were not available at $350 \mathrm{~m}$ on December 12-15. Meteorological parameters such as temperature, relative humidity, wind speed, and wind direction were also measured. 


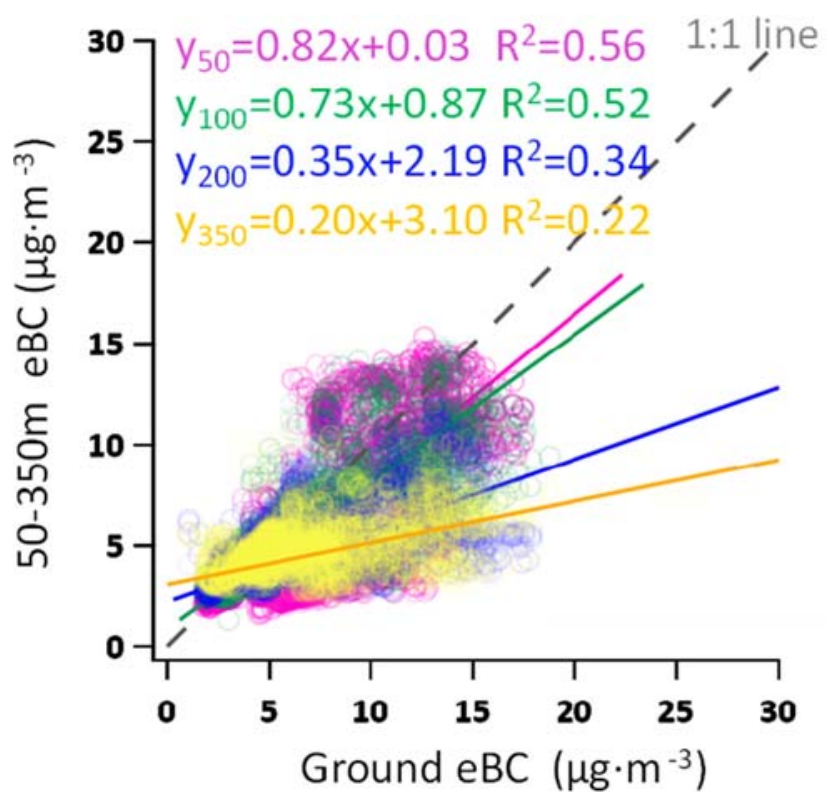

Fig. 3 Linear relationships between eBC concentrations at different heights

\subsection{Data processing}

The AE51 and MA200 are capable of acquiring eBC data at high time resolution (1 s), but are subject to optical and electronic noise at lower eBC concentrations. The Optimized Noise-reduction Averaging (ONA) algorithm (Hagler et al. 2011) was therefore applied for signal noise reduction. The ONA treatment results are shown as black lines in Fig. S2. The data logging interval used in this study is $1 \mathrm{~min}$ for AE51 and $1 \mathrm{~s}$ for MA200. The higher time resolution used in MA200 leads to a noisier signal of the raw data (shown as red dots in Fig. S2). It is worth noting that the negative values of the raw data do not reflect any physical meanings of the eBC concentrations. These are just raw data that need ONA treatment. The data fluctuation was minimized after ONA treatment as shown by the black lines in Fig. S2. After ONA treatment, the data were further corrected for the loading effect following the algorithm proposed by Virkkula et al. (2007). The loading correction equations are shown below:

$\mathrm{BC}_{\text {corrected }}=(1+k \times \mathrm{ATN}) \mathrm{BC}_{0}$

$k_{i}=\frac{1}{\operatorname{ATN}_{\left(t_{i, \text { ast }}\right)}}\left(\frac{\mathrm{BC}_{0}\left(t_{i+1, \text { first }}\right)}{\mathrm{BC}_{0}\left(t_{i, \text { last }}\right)}\right)$

where $\mathrm{BC}_{0}$ is the raw $\mathrm{BC}$ concentration reported by the aethalometer; ATN is the light attenuation measured by aethalometer; $k$ is an empirical constant that can be derived from Eq. $2 ; t_{i}$ last is the time of the last measurement data for filter spot $i$; and $t_{i+1}$, first is the time of the first measurement data for the next filter spot. For each spot (sampling cycle), a factor $k_{i}$ is obtained to correct the data according to Eq. 1. As shown by the blue lines in Fig. S2, the divergence of BC before and after filter change was effectively minimized by the correction scheme.

An Igor Pro (WaveMetrics, Inc., Lake Oswego, OR, USA) based program (MA Toolkit) was developed to incorporate both ONA and loading correction for MA200 and AE51 (Fig. S3).

Inter-instrument comparisons were conducted to ensure consistency between the MA200, AE51, and stationary reference instruments. In this study, a rack-mounted AE33 aethalometer (Drinovec et al. 2015) was used as the reference instrument. As shown in Fig. S4, the MA200 and AE51 correlate well with the AE33. As a result, the given slopes were used to correct the AE51 and MA200 data to ensure data consistency in this study. The AE51 had been proved as a suitable tool for ambient measurements in previous evaluation studies (Cheng and Lin 2013; Viana et al. 2015). We conducted extensive field tests on the MA200, and the systematic characterization of MA200 will be discussed in a separate paper in detail (Wu et al. 2020). Another two Igor Pro-based programs, Histbox (Wu et al. 2018) and ScatterPlot (Wu and Yu 2018), were used for data visualization (box plot and scatter plot).

\section{Results and discussion}

\subsection{Characteristics of eBC concentration changes at different heights}

Figure 2 shows eBC concentration frequency distributions at five heights during the campaign. The average $\mathrm{eBC}$ concentrations at 2, 50,100, 200, and $350 \mathrm{~m}$ are $6.6 \pm 3.6,5.4 \pm 3.3$, $5.9 \pm 2.8,5.2 \pm 1.8$, and $4.9 \pm 1.4 \mu \mathrm{g} \mathrm{m}^{-3}$, respectively, showing a decreasing trend with height (Fig. 2f). The mode concentrations of eBC (from 2 to $350 \mathrm{~m}$, respectively) are $4.1 \pm$ $0.5,3.3 \pm 0.3,4.1 \pm 0.4,4.3 \pm 0.3$, and $4.4 \pm 0.2 \mu \mathrm{g} \mathrm{m}^{-3}$. $\mathrm{eBC}$ features a bimodal distribution at 2 and $50 \mathrm{~m}$, and a unimodal distribution at 100, 200, and $350 \mathrm{~m}$. This implies that episodic events affect the surface levels ( 2 and $50 \mathrm{~m}$ ) more than they do the upper levels $(100,200$, and $350 \mathrm{~m})$.

\subsection{Linear relationships between eBC concentrations at different heights}

Linear relationships between eBC concentrations at different heights are shown in Fig. 3. It should be noted that considering the measurement uncertainties and the relatively short sampling period, the results shown here should not be interpreted to a high degree of accuracy. The slopes represent the ratios of $\mathrm{eBC}$ at $50,100,200$, and $350 \mathrm{~m}$ to $\mathrm{eBC}$ at $2 \mathrm{~m}$, which are $0.82,0.73,0.35$, and 0.20 , respectively (Fig. 3). All $p$ values of slopes at different heights 
Fig. 4 Diurnal variations in eBC at five heights. Red circles represent hourly averages, the lines inside the boxes indicate the hourly medians, the upper and lower boundaries of the boxes represent the 75th and 25th percentiles, and the whiskers above and below each box represent the 95th and 5th percentiles
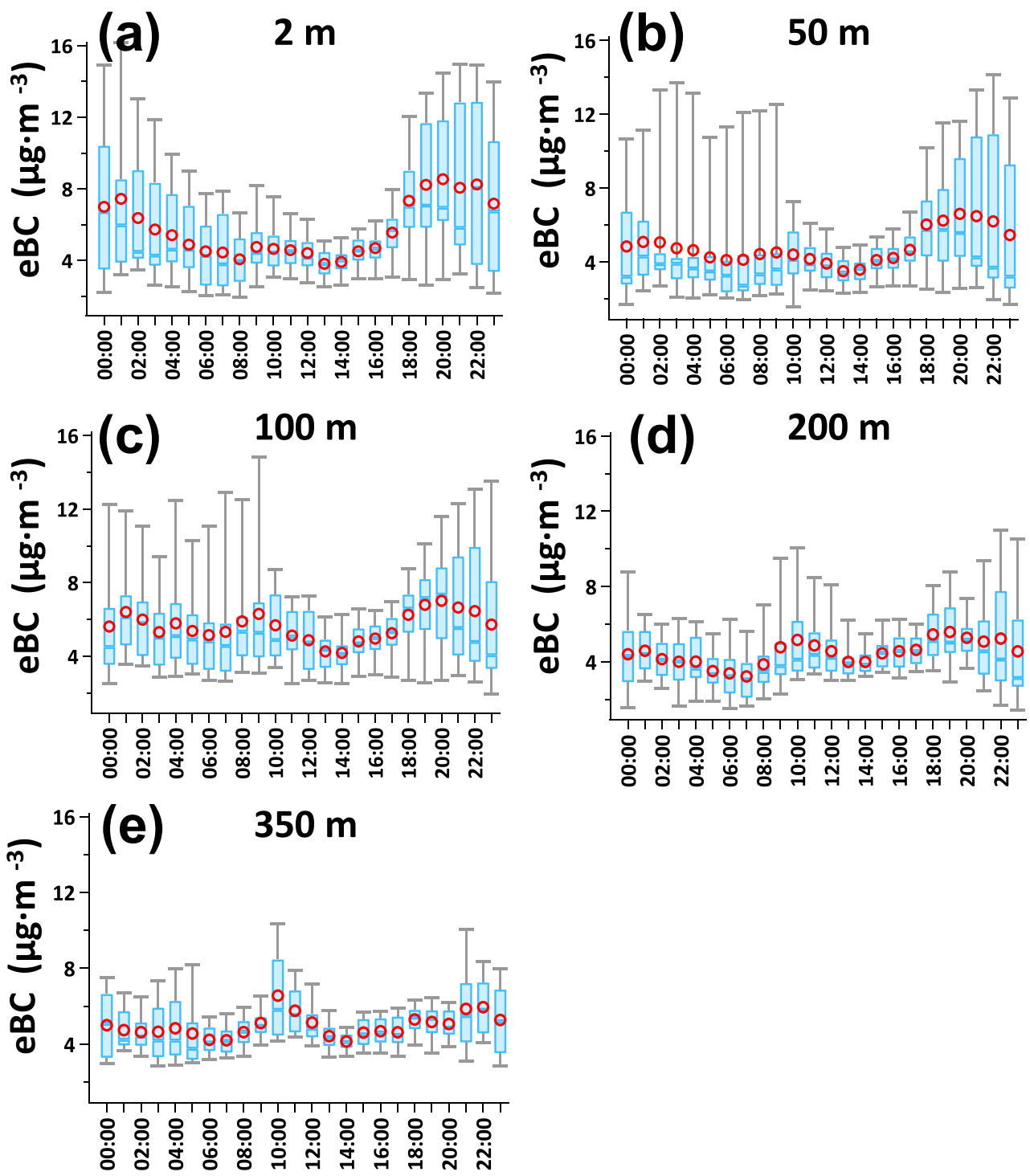

were 0.000 , suggesting that all slopes are significantly different from zero. The slopes at 50 and $100 \mathrm{~m}$ are similar, but those at 200 and $350 \mathrm{~m}$ decrease substantially. In contrast, the intercept increased with height, from 0.03 to 3.1. In addition, the relatively larger intercepts at the upper two levels (2.19 at $200 \mathrm{~m}$ and 3.10 at $350 \mathrm{~m}$ ) suggest a large fraction of the concentration variations cannot be explained by the linear relationship. Besides intercept, $R^{2}$ decreases with height, from 0.56 to 0.22 as shown in Fig. 3. The large intercept and low $R^{2}$ found at 200 and $350 \mathrm{~m}$ imply that the variations of $\mathrm{BC}$ at these two heights were less associated with ground-level $\mathrm{BC}$ comparing with 50 and $100 \mathrm{~m}$.

\section{3 eBC diurnal variations at different heights}

eBC diurnal variations are shown at five heights on the SZMT in Figs. 4 and 5. The eBC diurnal variations clearly show bimodal patterns at all five heights, with peaks appearing between 09:00 and 10:00 in the morning and between 19:00 and 21:00 in the evening. Minima occur from 13:00 to 14:00 in the afternoon and from 06:00 to 07:00 in the morning. Vehicle emissions likely drive the elevated $\mathrm{eBC}$ near the morning and evening rush hours. The evening peak is higher in magnitude and broader, which may be associated with traffic regulations in Shenzhen, where trucks are banned in urban areas from 7:00 to 22:00. Because trucks typically have higher emission factors, this truck ban may contribute to the large evening peak observed in this study. Higher emission combining the generally shadow mixing height during the evening leads to the enrichment of BC near the surface as shown in Fig. 5d. The minimum from 13:00 to $14: 00$ is associated with the gradual decrease in traffic volume after the morning rush hour and the increase in solar radiation in the afternoon, which causes strong atmospheric turbulence (i.e., mixing) and elevation of the boundary layer (i.e., dilution) (Tiwari et al. 2013). 

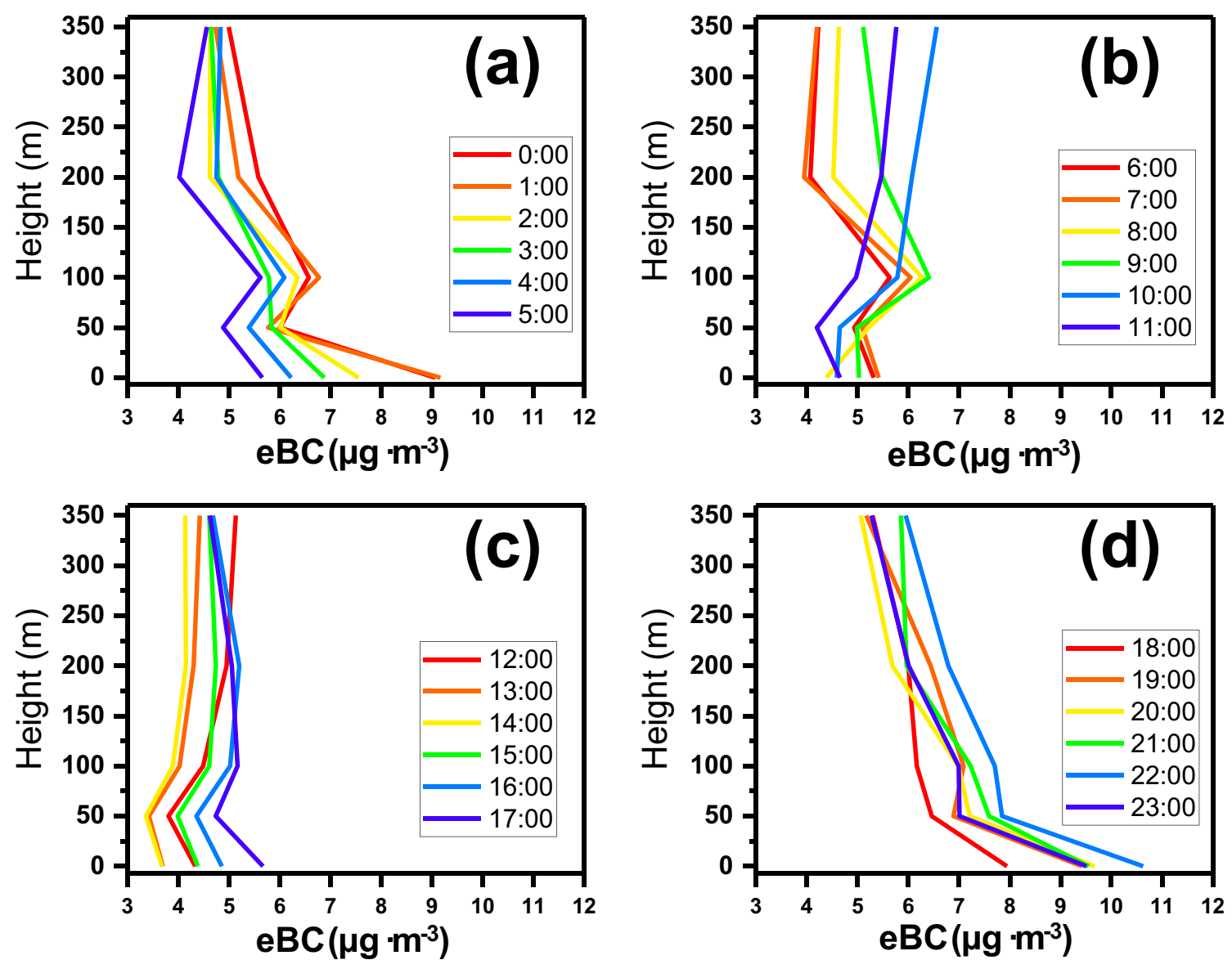

Fig. 5 Temporal variations of eBC vertical profiles

With the full development of the mixing layer, the vertical profiles are straight in the afternoon (Fig. 5c). The magnitude of the morning peak is comparable at all five heights, while the magnitude of the evening peak decreases significantly with height. This may imply that the emission source of the evening peak is closer to the sampling site than the emission source of the morning peak, as an emission source closer to the measurement site is expected to produce a more pronounced $\mathrm{eBC}$ vertical gradient.

\subsection{Temporal variations in $\mathrm{eBC}$ and $\mathrm{PM}_{2.5}$ at different heights}

Temporal variations in $\mathrm{eBC}$ and $\mathrm{PM}_{2.5}$ are shown at five heights in Fig. 6. The eBC and $\mathrm{PM}_{2.5}$ trends are similar at all five heights during most of the sampling period. The eBC-to- $\mathrm{PM}_{2.5}$ ratio from ground to $350 \mathrm{~m}$ is about $15 \%$, $8 \%, 11 \%, 9 \%$, and $10 \%$, respectively. The $\mathrm{eBC} / \mathrm{PM}_{2.5}$ mass ratio could potentially be an indicator for $\mathrm{PM}_{2.5}$ composition
Fig. 6 Temporal variations in $\mathrm{eBC}$ and $\mathrm{PM}_{2.5}$ at five heights. $\mathrm{PM}_{2.5}$ (shaded areas) is plotted on the right y-axis, while $\mathrm{eBC}$ (solid lines) is plotted on the left y-axis

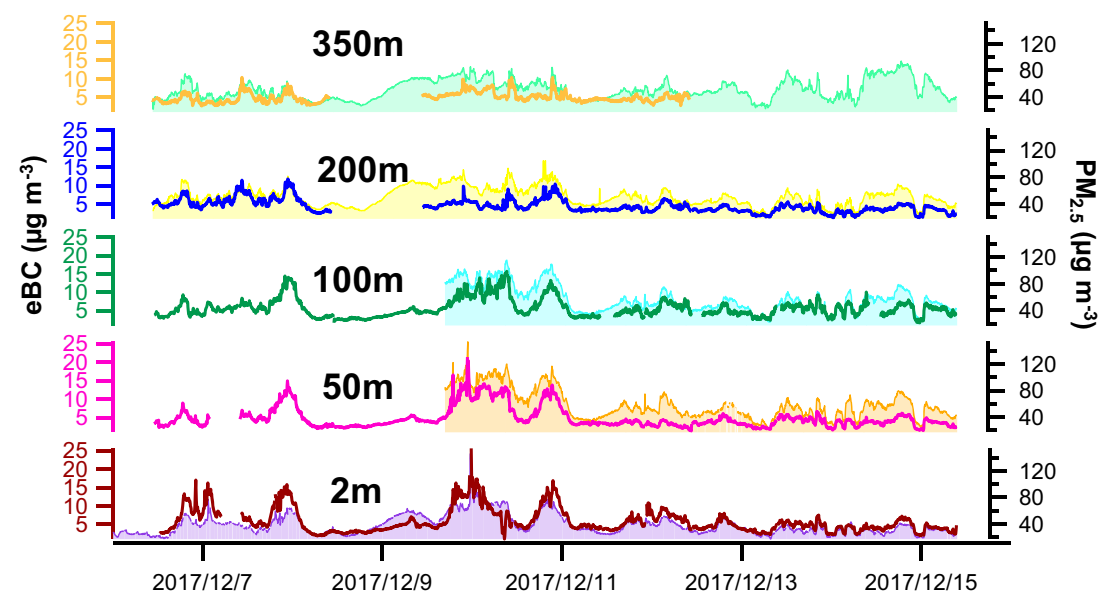


Fig. 7 Temporal variations in temperature $(\mathrm{T})$, relative humidity $(\mathrm{RH})$, solar radiation $(\mathrm{R})$ and $\mathrm{eBC}$ at five heights. Temperature (solid lines) are plotted on the left axis; RH (shaded areas) and eBC (solid lines) are plotted on the right axis

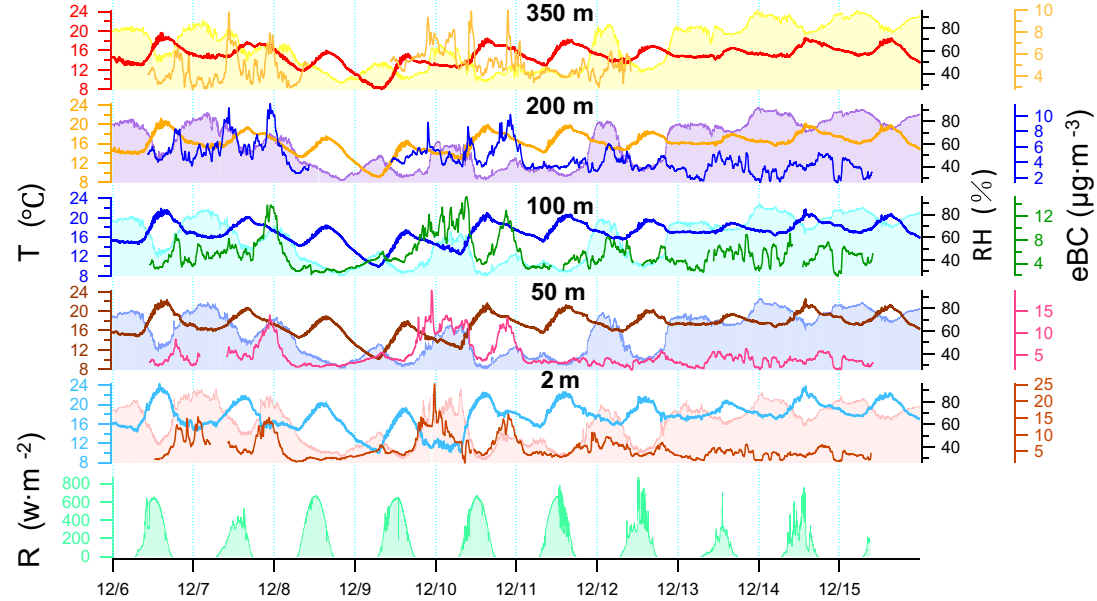

and sources. For the same height, occasionally the eBC/PM 2.5 ratio could be lower (e.g., December 9, 2017, at ground level), which implies the increase of non-BC fraction in $\mathrm{PM}_{2.5}$ (e.g., secondary aerosol formation). The occasional increase or spikes of the eBC/PM 2.5 ratio (e.g. December 10, 2017, 2 and $50 \mathrm{~m}$ ) may suggest the passing by of a primary emission plume that is rich in BC-containing contents (e.g., individual high emission vehicles or combustion events). The differences in eBC/PM 2.5 between different heights can also provide some qualitative source information. For example, eBC/PM 2.5 is highest at $2 \mathrm{~m}$, in agreement with the fact that most $\mathrm{BC}$ particles are emitted at the ground level.

\subsection{Effect of meteorological factors on eBC temporal variations}

On December 6, the region was experiencing the final stages of a cold episode. December 7-11 featured a cold high-pressure degeneration process, during which a stagnant zone formed near the ground, causing heavy pollution; December 12-15 featured southward movement of the cold air mass.
Temporal variations in temperature $(\mathrm{T})$, relative humidity (RH), solar radiation (R), and $\mathrm{eBC}$ are shown in Fig. 7. Solar radiation drives both $\mathrm{T}$ and $\mathrm{RH}$; $\mathrm{T}$ increases as solar radiation increases, leading to decreased $\mathrm{RH}$ in the afternoon. Both $\mathrm{T}$ and the amplitude of the variations in $\mathrm{RH}$ decrease with increasing height. Under sufficient solar radiation (December 6-11), decreases in T lead to more variable RH diurnal patterns; however, under cloudy conditions, when solar radiation is blocked (December 12-15), the diurnal variations in $\mathrm{RH}$ are much less pronounced at all heights. It can be seen from Fig. 7 that the trend of eBC concentration is similar to the trend of $\mathrm{RH}$, which is generally opposite to the trend of $\mathrm{T}$.

Figure 8 shows the effect of wind speed on eBC concentrations at five altitudes. Wind speed increases significantly with height, measuring two-fold higher at $350 \mathrm{~m}$ than at ground level. High wind speeds likely contribute to the decrease in eBC with height (Bibi et al. 2017). The eBC episode during December 9-10 was likely driven primarily by the low wind speed during this period, confirming the key role of wind speed, among other meteorological factors, in the observed eBC concentrations.
Fig. 8 Temporal variations in $\mathrm{eBC}$ and wind speed at five heights. eBC (solid lines) is plotted on the left axis. Wind speed (WS; shaded areas) is plotted on the right axis

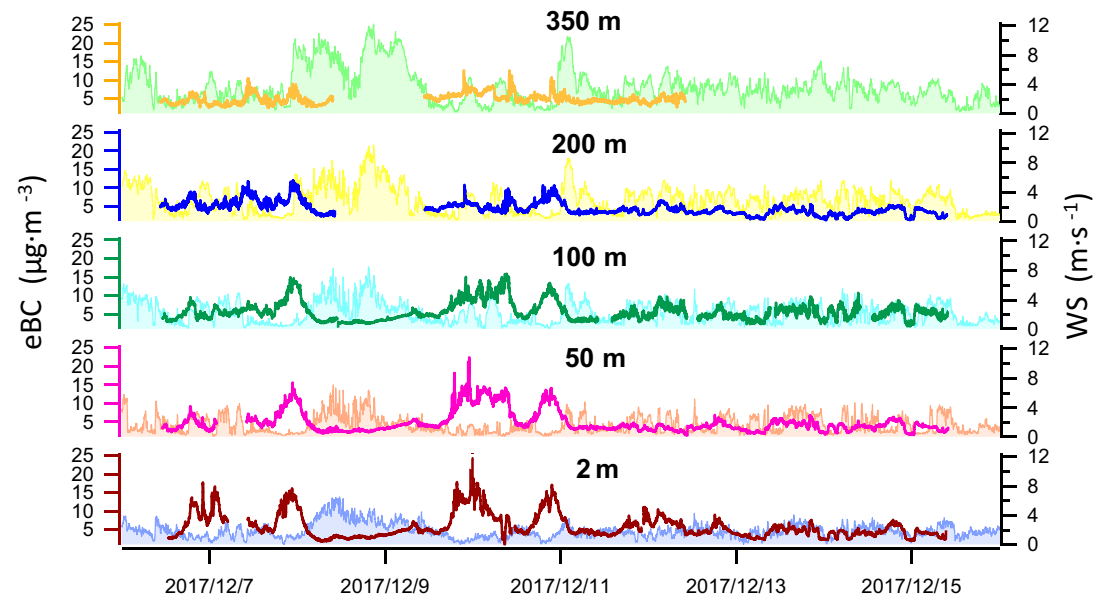


Fig. 9 eBC wind-rose plots for the five sampling heights. The left column shows the distributions of eBC concentration as a function of wind speed and wind direction at the five heights, where the color represents the $\mathrm{eBC}$ concentration. The right column shows the probability of wind arising from the given wind direction, where the color represents probability

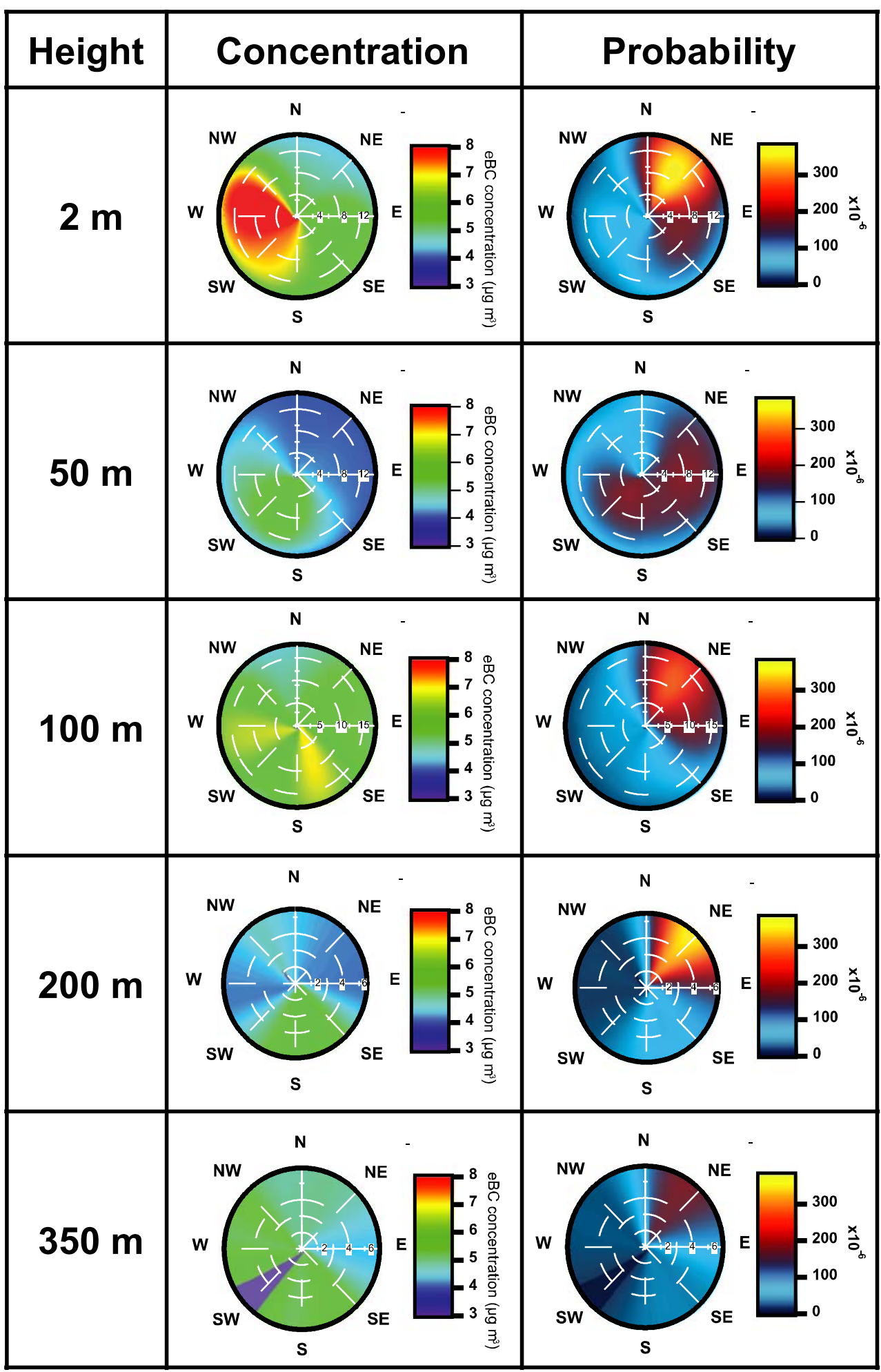

\subsection{Influence of wind direction on $\mathrm{eBC}$ concentrations}

Figure 9 shows eBC wind-rose plots that were generated using ZeFir (Petit et al. 2017) for the five sampling heights. The results suggest that high $\mathrm{eBC}$ concentrations come from different directions at different heights. At $2 \mathrm{~m}$, high eBC concentrations arise mainly from the west, but occur relatively infrequently since northwest winds are dominant. At $50 \mathrm{~m}$, high eBC episodes arise mainly from the southwest. At $100 \mathrm{~m}$, elevated $\mathrm{eBC}$ is associated with both southerly and westerly winds. At 100, 200, and $350 \mathrm{~m}$, northeasterly winds are dominant; however, high $\mathrm{eBC}$ events arise from different 
Fig. 10 Seventy-two-hour backward trajectory clusters at a height of $100 \mathrm{~m}$. The box plot shows eBC concentrations for the different clusters

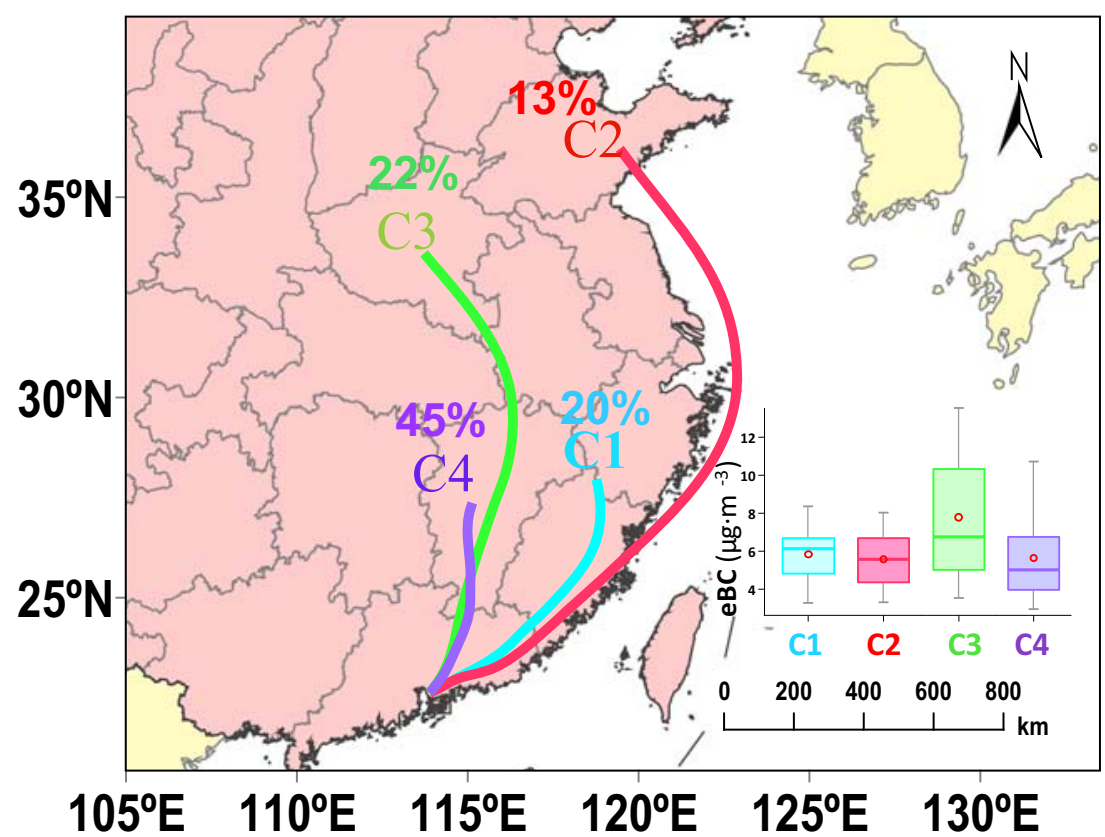

directions at different heights, confirming that local primary emission plumes contribute to these events.

\subsection{Backward trajectory cluster analysis}

Backward trajectory cluster analysis has proven useful for exploring relationships between air pollutants and their air mass origins (Stein et al. 2015). In this study, 72-h backward trajectories were calculated on an hourly basis in Metinfo (Wang 2014) using GDAS data from the National Oceanic and Atmospheric Administration (NOAA). The resulting

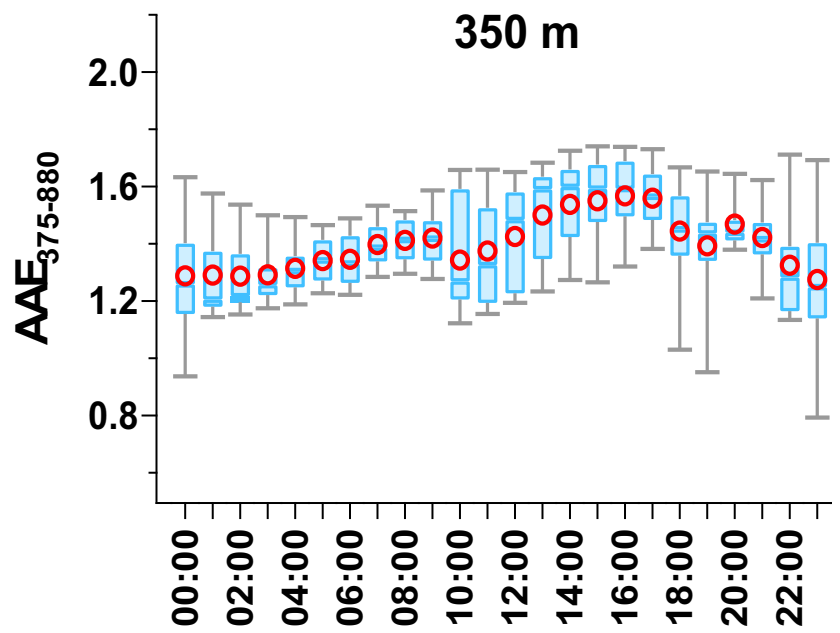

Fig. 11 Diurnal variations in $\mathrm{AAE}_{375-880}$ measured at $350 \mathrm{~m}$. The red circles represent the hourly averages, the lines inside the boxes indicate the hourly medians, the upper and lower boundaries of the boxes represent the 75th and the 25th percentiles, and the whiskers above and below each box represent the 95 th and 5 th percentiles backward trajectories were then subjected to cluster analysis, producing four clusters $(\mathrm{C} 1-\mathrm{C} 4)$.

Figure 10 shows the 72-h backward trajectory clusters and corresponding eBC concentrations at $100 \mathrm{~m}$. During the sampling period, the region was affected by a northeastern monsoon and thus dominated by air masses transported from the northeast. The fractional contributions of the four clusters are, in descending order: $\mathrm{C} 4(45 \%)>\mathrm{C} 3(22 \%)>\mathrm{C} 1(20 \%)>\mathrm{C} 2$ $(13 \%)$. The highest $\mathrm{eBC}$ concentrations are found in $\mathrm{C} 3(7.8 \pm$ $\left.3.4 \mu \mathrm{g} \mathrm{m}^{-3}\right)$, followed by $\mathrm{C} 1\left(5.8 \pm 1.5 \mu \mathrm{g} \mathrm{m}^{-3}\right), \mathrm{C} 4(5.6 \pm$ $\left.1.6 \mu \mathrm{g} \mathrm{m}^{-3}\right)$, and $\mathrm{C} 2\left(5.6 \pm 2.5 \mu \mathrm{g} \mathrm{m}^{-3}\right)$. $\mathrm{C} 3$ originates from inland central China, and $\mathrm{C} 1$ and $\mathrm{C} 4$ possess shorter paths than do $\mathrm{C} 2$ and $\mathrm{C} 3$, implying lower wind speeds during air mass transport. The results identify central China as an important long-range contributor to eBC levels in Shenzhen, which consisted with previous research on $\mathrm{EBC}$ in Shenzhen (Cheng et al. 2018).

\subsection{Absorption Ångström exponent variations}

The absorption Ångström exponent (AAE) can be used to quantify the wavelength-dependent absorption characteristics of $\mathrm{BC}$ aerosols. AAE is calculated using light absorption at two wavelengths via (Moosmüller et al. 2011):

$\operatorname{AAE}\left(\lambda_{1}, \lambda_{2}\right)=-\frac{\ln \left(\sigma_{a b s, \lambda 1}\right)-\ln \left(\sigma_{a b s, \lambda 2}\right)}{\ln \left(\lambda_{1}\right)-\ln \left(\lambda_{2}\right)}$

In this study, $375 \mathrm{~nm}$ and $880 \mathrm{~nm}$ were used to determine $\mathrm{AAE}_{375-880}$. Due to limited multi-wavelength data availability at $200 \mathrm{~m}$, the $\mathrm{AAE}_{375-880}$ at $350 \mathrm{~m}$ was used in the diurnal variation analysis. 
Diurnal variations in $\mathrm{AAE}_{375-880}$ at $350 \mathrm{~m}$ are shown in Fig. 11, in which the hourly average values range from 1.2 to 1.5. The $\mathrm{AAE}_{375-880}$ diurnal maximum occurs at 16:00, while the diurnal minimum is found at 23:00. The local $\mathrm{AAE}_{375-880}$ minimum at 10:00 may arise from an increase in freshly emitted $\mathrm{BC}$ particles during the morning rush hour (with a 1-2-h delay due to the required vertical dispersion). The decrease in $\mathrm{AAE}_{375-880}$ in the evening may be associated with a combination of evening rush hour and truck regulation (trucks are banned from urban areas from 7:00 to 22:00). The increase in $\mathrm{AAE}_{375-880}$ in the afternoon may be associated with the aging of BC particles (Lack and Cappa 2010). The $\mathrm{AAE}_{375-880}$ at $350 \mathrm{~m}$ (1.31) is slightly higher than that at $200 \mathrm{~m}$ (1.26), as shown in Fig. S5. Our hypothesis for the increase in $\mathrm{AAE}_{375}$ 880 with height was associated with particles aging during vertical transport. Since the difference is relatively small (1.31 vs. 1.26 ), more evidence is needed to verify this hypothesis in future study.

\section{Conclusions}

In this study, $\mathrm{eBC}$ variations were measured at five altitudes $(2,50,100,200$, and $350 \mathrm{~m})$ using the 356-m Shenzhen meteorological tower (SZMT). During the observation period, the average $\mathrm{eBC}$ concentrations were, from 2 to $350 \mathrm{~m}, 6.6$ $\pm 3.6,5.4 \pm 3.3,5.9 \pm 2.8,5.2 \pm 1.8$, and $4.9 \pm 1.4 \mu \mathrm{g} \mathrm{m}^{-3}$, respectively. The temporal variations in $\mathrm{eBC}$ at different heights were well correlated, and the $\mathrm{eBC}$ concentrations decreased with height; the ground-level eBC concentration was 1.2 times that at $50 \mathrm{~m}, 1.4$ times that at $100 \mathrm{~m}, 2.8$ times that at $200 \mathrm{~m}$, and 4.9 times that at $350 \mathrm{~m}$. At all five heights, the eBC diurnal variations featured a bimodal pattern, with peaks appearing between 09:00 and 10:00 in the morning and between 19:00 and 21:00 in the evening. The magnitude of the evening peak decreased with height.

The $\mathrm{eBC}$-to- $\mathrm{PM}_{2.5}$ ratio was relatively stable throughout the campaign. eBC episodes were largely driven by low wind speed, and, considering the increase in wind speed with height, wind speed likely played a key role in the observed eBC concentrations, among other meteorological factors. eBC wind-rose analysis suggested that high $\mathrm{eBC}$ events arose from different directions at different heights, confirming the contribution of local primary emission plumes. In the backward trajectory cluster analysis, air masses from central China exhibited much higher eBC levels than the remaining three backward trajectory clusters. The $\mathrm{AAE}_{375-880}$ at $350 \mathrm{~m}$ showed clear diurnal variations, which may have been associated with both $\mathrm{eBC}$ aging and varying fractional contributions of freshly emitted eBC. A slightly increasing trend in $\mathrm{AAE}_{375-880}$ with height was observed.

Although meteorological towers enable time-resolved vertical measurements, the vertical resolution is relatively coarse (e.g., five heights in this study) and is limited by the availability of observation decks of a tower. In contrast, batterypowered UAV can provide higher vertical resolution (e.g., $1 \sim 10 \mathrm{~m}$ ) and better vertical coverage (e.g., $\sim 1 \mathrm{~km}$ ). However, current battery technology limits the UAV flight time of a single flight (less than $1 \mathrm{~h}$ ), leading to poor temporal coverage. Incorporating these two complementary approaches for co-located measurements in the future study can provide more insights into the characterization of $\mathrm{BC}$ vertical profiles.

Acknowledgments The authors would like to thank the maintenance team at the 356-m metrological tower for their help in instrument installation. The authors gratefully acknowledge the NOAA Air Resources Laboratory (ARL) for providing the HYSPLIT transport and dispersion model used in this work.

Funding information This work was supported by the National Natural Science Foundation of China $(41605002,41475004)$ and State Key Laboratory of Organic Geochemistry, GIGCAS (Grant No. SKLOG201725).

Open Access This article is licensed under a Creative Commons Attribution 4.0 International License, which permits use, sharing, adaptation, distribution and reproduction in any medium or format, as long as you give appropriate credit to the original author(s) and the source, provide a link to the Creative Commons licence, and indicate if changes were made. The images or other third party material in this article are included in the article's Creative Commons licence, unless indicated otherwise in a credit line to the material. If material is not included in the article's Creative Commons licence and your intended use is not permitted by statutory regulation or exceeds the permitted use, you will need to obtain permission directly from the copyright holder. To view a copy of this licence, visit http://creativecommons.org/licenses/by/4.0/.

\section{References}

Andreae MO, Acevedo OC, Araùjo A, Artaxo P, Barbosa CGG, Barbosa HMJ, Brito J, Carbone S, Chi X, Cintra BBL, da Silva NF, Dias NL, Dias-Júnior CQ, Ditas F, Ditz R, Godoi AFL, Godoi RHM, Heimann M, Hoffmann T, Kesselmeier J, Könemann T, Krüger ML, Lavric JV, Manzi AO, Lopes AP, Martins DL, Mikhailov EF, Moran-Zuloaga D, Nelson BW, Nölscher AC, Santos Nogueira D, Piedade MTF, Pöhlker C, Pöschl U, Quesada CA, Rizzo LV, Ro CU, Ruckteschler N, Sá LDA, de Oliveira Sá M, Sales CB, dos Santos RMN, Saturno J, Schöngart J, Sörgel M, de Souza CM, de Souza RAF, Su H, Targhetta N, Tóta J, Trebs I, Trumbore S, van Eijck A, Walter D, Wang Z, Weber B, Williams J, Winderlich J, Wittmann F, Wolff S, Yáñez-Serrano AM (2015) The Amazon Tall Tower Observatory (ATTO): overview of pilot measurements on ecosystem ecology, meteorology, trace gases, and aerosols. Atmos Chem Phys 15:10723-10776. https://doi.org/10.5194/acp-15-10723-2015

Babu SS, Moorthy KK, Manchanda RK, Sinha PR, Satheesh SK, Vajja DP, Srinivasan S, Kumar VHA (2011) Free tropospheric black carbon aerosol measurements using high altitude balloon: do BC layers build "their own homes" up in the atmosphere? Geophys Res Lett 38:L08803. https://doi.org/10.1029/2011gl046654

Bibi S, Alam K, Chishtie F, Bibi H, Rahman S (2017) Temporal variation of Black Carbon concentration using Aethalometer observations and its relationships with meteorological variables in Karachi, Pakistan. 
J Atmos Sol-Terr Phys:157-158. https://doi.org/10.1016/j.jastp. 2017.03.017

Bisht DS, Tiwari S, Dumka UC, Srivastava AK, Safai PD, Ghude SD, Chate DM, Rao PSP, Ali K, Prabhakaran T, Panickar AS, Soni VK, Attri SD, Tunved P, Chakrabarty RK, Hopke PK (2016) Tethered balloon-born and ground-based measurements of black carbon and particulate profiles within the lower troposphere during the foggy period in Delhi, India. Sci.Total.Environ. 573:894-905. https://doi. org/10.1016/j.scitotenv.2016.08.185

Bond TC, Bergstrom RW (2006) Light absorption by carbonaceous particles: An investigative review. Aerosol Sci Technol 40:27-67. https://doi.org/10.1080/02786820500421521

Bond TC, Doherty SJ, Fahey DW, Forster PM, Berntsen T, DeAngelo BJ, Flanner MG, Ghan S, Karcher B, Koch D, Kinne S, Kondo Y, Quinn PK, Sarofim MC, Schultz MG, Schulz M, Venkataraman C, Zhang H, Zhang S, Bellouin N, Guttikunda SK, Hopke PK, Jacobson MZ, Kaiser JW, Klimont Z, Lohmann U, Schwarz JP, Shindell D, Storelvmo T, Warren SG, Zender CS (2013) Bounding the role of black carbon in the climate system: A scientific assessment. J Geophys Res 118:5380-5552. https://doi.org/10.1002/jgrd.50171

Borm PJA, Schins RPF, Albrecht C (2004) Inhaled particles and lung cancer, part B: paradigms and risk assessment. Int J Cancer 110:314. https://doi.org/10.1002/ijc.20064

Chen Y, Schleicher N, Fricker M, Cen K, Liu X-L, Kaminski U, Yu Y, Wu X-F, Norra S (2016) Long-term variation of black carbon and PM2.5 in Beijing, China with respect to meteorological conditions and governmental measures. Environ Pollut 212:269-278. https:// doi.org/10.1016/j.envpol.2016.01.008

Cheng Y-H, Lin M-H (2013) Real-time performance of the microAeth ${ }^{\circledR}$ AE51 and the effects of aerosol loading on its measurement results at a traffic site. Aerosol Air Qual Res 13:1853-1863. https://doi.org/ 10.4209/aaqr.2012.12.0371

Cheng D, Cheng WU, Dui WU, Liu J, Song L, Sun T-1, Mao Xia, Jiang Y, Liu A-M (2018) Comparative study on the characteristics of black carbon aerosol in urban and suburban areas of Shenzhen. China Environ Sci 38:1653-1662. https://doi.org/10.19674/j.cnki. issn1000-6923.2018.0195. (In Chinese)

Chi X, Winderlich J, Mayer JC, Panov AV, Heimann M, Birmili W, Heintzenberg J, Cheng Y, Andreae MO (2013) Long-term measurements of aerosol and carbon monoxide at the ZOTTO tall tower to characterize polluted and pristine air in the Siberian taiga. Atmos Chem Phys 13:12271-12298. https://doi.org/10.5194/acp-1312271-2013

CNEMC (China National Environmental Monitoring Center) (2018) National air quality report of December 2017. http://www.cnemc. cn/jcbg/kqzlzkbg/201801/P020181010529640379509.pdf. Accessed 3 Mar 2020

Corrigan CE, Roberts GC, Ramana MV, Kim D, Ramanathan V (2008) Capturing vertical profiles of aerosols and black carbon over the Indian Ocean using autonomous unmanned aerial vehicles. Atmos Chem Phys 8:737-747. https://doi.org/10.5194/acp-8-737-2008

Deng X, Li F, Li Y, Li J, Huang H, Liu X (2015) Vertical distribution characteristics of PM in the surface layer of Guangzhou. Particuology 20:3-9. https://doi.org/10.1016/j.partic.2014.02.009

Ding AJ, Huang X, Nie W, Sun JN, Kerminen VM, Petäjä T, Su H, Cheng YF, Yang XQ, Wang MH, Chi XG, Wang JP, Virkkula A, Guo WD, Yuan J, Wang SY, Zhang RJ, Wu YF, Song Y, Zhu T, Zilitinkevich S, Kulmala M, Fu CB (2016) Enhanced haze pollution by black carbon in megacities in China. Geophys Res Lett 43:2873-2879. https://doi.org/10.1002/2016GL067745

Drinovec L, Močnik G, Zotter P, Prévôt ASH, Ruckstuhl C, Coz E, Rupakheti M, Sciare J, Müller T, Wiedensohler A, Hansen ADA (2015) The "dual-spot" aethalometer: an improved measurement of aerosol black carbon with real-time loading compensation. Atmos Meas Tech 8:1965-1979. https://doi.org/10.5194/amt-81965-2015
Ferrero L, Mocnik G, Ferrini BS, Perrone MG, Sangiorgi G, Bolzacchini E (2011) Vertical profiles of aerosol absorption coefficient from micro-Aethalometer data and Mie calculation over Milan. Sci.Total.Environ. 409:2824-2837. https://doi.org/10.1016/j. scitotenv.2011.04.022

Ferrero L, Castelli M, Ferrini BS, Moscatelli M, Perrone MG, Sangiorgi G, D'Angelo L, Rovelli G, Moroni B, Scardazza F, Močnik G, Bolzacchini E, Petitta M, Cappelletti D (2014) Impact of black carbon aerosol over Italian basin valleys: high-resolution measurements along vertical profiles, radiative forcing and heating rate. Atmos Chem Phys 14:9641-9664. https://doi.org/10.5194/acp-149641-2014

Ferrero L, Cappelletti D, Busetto M, Mazzola M, Lupi A, Lanconelli C, Becagli S, Traversi R, Caiazzo L, Giardi F, Moroni B, Crocchianti S, Fierz M, Močnik G, Sangiorgi G, Perrone MG, Maturilli M, Vitale V, Udisti R, Bolzacchini E (2016) Vertical profiles of aerosol and black carbon in the Arctic: a seasonal phenomenology along 2 years (2011-2012) of field campaigns. Atmos Chem Phys 16:1260112629. https://doi.org/10.5194/acp-16-12601-2016

Hagler GSW, Yelverton TLB, Vedantham R, Hansen ADA, Turner JR (2011) Post-processing method to reduce noise while preserving high time resolution in aethalometer real-time black carbon data. Aerosol Air Qual Res 11:539-546. https://doi.org/10.4209/aaqr. 2011.05.0055

Hansen ADA, Rosen H, Novakov T (1984) The aethalometer - an instrument for the real-time measurement of optical-absorption by aerosol-particles. Sci.Total.Environ. 36:191-196. https://doi.org/10. 1016/0048-9697(84)90265-1

He H, Sun M, Liu A (2009a) Vertical distribution of air pollutants in the atmosphere in Tianjin. Acta Sci Circumst 29:2478-2483

He X, Li CC, Lau AKH, Deng ZZ, Mao JT, Wang MH, Liu XY (2009b) An intensive study of aerosol optical properties in Beijing urban area. Atmos Chem Phys 9:8903-8915. https://doi.org/10.5194/acp9-8903-2009

Highwood EJ, Kinnersley RP (2006) When smoke gets in our eyes: the multiple impacts of atmospheric black carbon on climate, air quality and health. Environ Int 32:560-566. https://doi.org/10.1016/j. envint.2005.12.003

Ji D, Li L, Pang B, Xue P, Wang L, Wu Y, Zhang H, Wang Y (2017) Characterization of black carbon in an urban-rural fringe area of Beijing. Environ Pollut 223:524-534. https://doi.org/10.1016/j. envpol.2017.01.055

Keegan M (2018) Shenzhen's silent revolution: world's first fully electric bus fleet quietens Chinese megacity. The Guardian. https://www. theguardian.com/cities/2018/dec/12/silence-shenzhen-world-firstelectric-bus-fleet. Accessed 3 Mar 2020

Kirchstetter TW, Preble CV, Hadley OL, Bond TC, Apte JS (2017) Large reductions in urban black carbon concentrations in the United States between 1965 and 2000. Atmos Environ 151:17-23. https://doi.org/ 10.1016/j.atmosenv.2016.11.001

Kutzner RD, von Schneidemesser E, Kuik F, Quedenau J, Weatherhead EC, Schmale J (2018) Long-term monitoring of black carbon across Germany. Atmos Environ 185:41-52. https://doi.org/10.1016/j. atmosenv.2018.04.039

Lack DA, Cappa CD (2010) Impact of brown and clear carbon on light absorption enhancement, single scatter albedo and absorption wavelength dependence of black carbon. Atmos Chem Phys 10:42074220. https://doi.org/10.5194/acp-10-4207-2010

Li J, Fu Q, Huo J, Wang D, Yang W, Bian Q, Duan Y, Zhang Y, Pan J, Lin Y, Huang K, Bai Z, Wang S-H, Fu JS, Louie PKK (2015) Tethered balloon-based black carbon profiles within the lower troposphere of Shanghai in the 2013 East China smog. Atmos Environ 123(Part B): 327-338. https://doi.org/10.1016/j.atmosenv.2015.08.096

Li X-B, Wang D-S, Lu Q-C, Peng Z-R, Wang Z-Y (2018) Investigating vertical distribution patterns of lower tropospheric PM2.5 using 
unmanned aerial vehicle measurements. Atmos Environ 173:62-71. https://doi.org/10.1016/j.atmosenv.2017.11.009

Li L, Lu C, Chan P-W, Zhang X, Yang H-L, Lan Z-J, Zhang W-H, Liu YW, Pan L, Zhang L (2020) Tower observed vertical distribution of PM2.5, $\mathrm{O} 3$ and NOx in the Pearl River Delta. Atmos Environ 220: 117083. https://doi.org/10.1016/j.atmosenv.2019.117083

Liu B, Wu C, Ma N, Chen Q, Li Y, Ye J, Martin ST, Li YJ (2020) Vertical profiling of fine particulate matter and black carbon by using unmanned aerial vehicle in Macau, China. Sci.Total.Environ.:136109. https://doi.org/10.1016/j.scitotenv.2019.136109

Lu Y, Zhu B, Huang Y, Shi S, Wang H, An J, Yu X (2019) Vertical distributions of black carbon aerosols over rural areas of the Yangtze River Delta in winter. Sci.Total.Environ. 661:1-9. https:// doi.org/10.1016/j.scitotenv.2019.01.170

Markowicz KM, Ritter C, Lisok J, Makuch P, Stachlewska IS, Cappelletti D, Mazzola M, Chilinski MT (2017) Vertical variability of aerosol single-scattering albedo and equivalent black carbon concentration based on in-situ and remote sensing techniques during the iAREA campaigns in Ny-Ålesund. Atmos Environ 164:431-447. https:// doi.org/10.1016/j.atmosenv.2017.06.014

Mishra SK, Ahlawat A, Khosla D, Sharma C, Prasad MVSN, Singh S, Gupta B, Tulsi SD, Sinha PR, Ojha DK, Wiedensohler A, Kotnala RK (2018) Experimental investigation of variations in morphology, composition and mixing-state of boundary layer aerosol: A balloon based study over urban environment (New Delhi). Atmos Environ 185:243-252. https://doi.org/10.1016/j.atmosenv.2018.04.053

Moosmüller H, Chakrabarty RK, Arnott WP (2009) Aerosol light absorption and its measurement: A review. J Quant Spectrosc Ra 110:844 878. https://doi.org/10.1016/j.jqsrt.2009.02.035

Moosmüller H, Chakrabarty RK, Ehlers KM, Arnott WP (2011) Absorption Angstrom coefficient, brown carbon, and aerosols: basic concepts, bulk matter, and spherical particles. Atmos Chem Phys 11: 1217-1225. https://doi.org/10.5194/acp-11-1217-2011

Petit JE, Favez O, Albinet A, Canonaco F (2017) A user-friendly tool for comprehensive evaluation of the geographical origins of atmospheric pollution: wind and trajectory analyses. Environ Model Softw 88: 183-187. https://doi.org/10.1016/j.envsoft.2016.11.022

Pikridas M, Bezantakos S, Močnik G, Keleshis C, Brechtel F, Stavroulas I, Demetriades G, Antoniou P, Vouterakos P, Argyrides M, Liakakou E, Drinovec L, Marinou E, Amiridis V, Vrekoussis M, Mihalopoulos N, Sciare J (2019) On-flight intercomparison of three miniature aerosol absorption sensors using unmanned aerial systems (UASs). Atmos Meas Tech 12:6425-6447. https://doi.org/10.5194/amt-126425-2019

Ramana MV, Ramanathan V, Feng Y, Yoon SC, Kim SW, Carmichael GR, Schauer JJ (2010) Warming influenced by the ratio of black carbon to sulphate and the black-carbon source. Nat Geosci 3:542. https://doi.org/10.1038/ngeo918

Ran L, Deng Z, Xu X, Yan P, Lin W, Wang Y, Tian P, Wang P, Pan W, Lu D (2016) Vertical profiles of black carbon measured by a microaethalometer in summer in the North China Plain. Atmos Chem Phys 16:10441-10454. https://doi.org/10.5194/acp-16-10441-2016

Reddy MS, Boucher O (2007) Climate impact of black carbon emitted from energy consumption in the world's regions. Geophys Res Lett 34:L11802. https://doi.org/10.1029/2006gl028904

Ren L, Zhang R, Yang X, Geng C, Wang W, Hatakeyama S, Li H, Yang W, Bai Z, Takami A, Liu H, Chen J (2018) Aircraft measurement of chemical characteristics of PM2.5 over the Yangtze River area in China. Aerosol Sci Eng 2:182-196. https://doi.org/10.1007/s41810018-0035-3

Rosati B, Herrmann E, Bucci S, Fierli F, Cairo F, Gysel M, Tillmann R, Größ J, Gobbi GP, Di Liberto L, Di Donfrancesco G, Wiedensohler A, Weingartner E, Virtanen A, Mentel TF, Baltensperger U (2016) Studying the vertical aerosol extinction coefficient by comparing in situ airborne data and elastic backscatter lidar. Atmos Chem Phys 16:4539-4554. https://doi.org/10.5194/acp-16-4539-2016
Ruppel MM, Isaksson I, Ström J, Beaudon E, Svensson J, Pedersen CA, Korhola A (2014) Increase in elemental carbon values between 1970 and 2004 observed in a 300-year ice core from Holtedahlfonna (Svalbard). Atmos Chem Phys 14:11447-11460. https://doi.org/10. 5194/acp-14-11447-2014

Safai PD, Raju MP, Maheshkumar RS, Kulkarni JR, Rao PSP, Devara PCS (2012) Vertical profiles of black carbon aerosols over the urban locations in South India. Sci.Total.Environ. 431:323-331. https:// doi.org/10.1016/j.scitotenv.2012.05.058

Samset BH, Myhre G, Schulz M, Balkanski Y, Bauer S, Berntsen TK, Bian H, Bellouin N, Diehl T, Easter RC, Ghan SJ, Iversen T, Kinne S, Kirkevåg A, Lamarque JF, Lin G, Liu X, Penner JE, Seland Ø, Skeie RB, Stier P, Takemura T, Tsigaridis K, Zhang K (2013) Black carbon vertical profiles strongly affect its radiative forcing uncertainty. Atmos Chem Phys 13:2423-2434. https://doi.org/10.5194/acp13-2423-2013

Schwarz JP, Spackman JR, Fahey DW, Gao RS, Lohmann U, Stier P, Watts LA, Thomson DS, Lack DA, Pfister L, Mahoney MJ, Baumgardner D, Wilson JC, Reeves JM (2008) Coatings and their enhancement of black carbon light absorption in the tropical atmosphere. J Geophys Res 113:D03203. https://doi.org/10.1029/ 2007JD009042

Sharma S, Lavoué D, Cachier H, Barrie LA, Gong SL (2004) Long-term trends of the black carbon concentrations in the Canadian Arctic. J Geophys Res 109:D15203. https://doi.org/10.1029/2003jd004331

Singh A, Mahata KS, Rupakheti M, Junkermann W, Panday AK, Lawrence MG (2019) An overview of airborne measurement in Nepal - part 1: vertical profile of aerosol size, number, spectral absorption, and meteorology. Atmos Chem Phys 19:245-258. https://doi.org/10.5194/acp-19-245-2019

Stein AF, Draxler RR, Rolph GD, Stunder BJB, Cohen MD, Ngan F (2015) NOAA's HYSPLIT atmospheric transport and dispersion modeling system. Bull Am Meteorol Soc 96:2059-2077. https:// doi.org/10.1175/bams-d-14-00110.1

Sun Y, Song T, Tang G, Wang Y (2013) The vertical distribution of PM2.5 and boundary-layer structure during summer haze in Beijing. Atmos Environ 74:413-421. https://doi.org/10.1016/j. atmosenv.2013.03.011

Tiwari S, Srivastava AK, Bisht DS, Parmita P, Srivastava MK, Attri SD (2013) Diurnal and seasonal variations of black carbon and PM 2.5 over New Delhi, India: influence of meteorology. Atmos Res 125126:50-62. https://doi.org/10.1016/j.atmosres.2013.01.011

Trompetter WJ, Grange SK, Davy PK, Ancelet T (2013) Vertical and temporal variations of black carbon in New Zealand urban areas during winter. Atmos Environ 75:179-187. https://doi.org/10. 1016/j.atmosenv.2013.04.036

Vaishya A, Babu SNS, Jayachandran V, Gogoi MM, Lakshmi NB, Moorthy KK, Satheesh SK (2018) Large contrast in the vertical distribution of aerosol optical properties and radiative effects across the Indo-Gangetic Plain during the SWAAMI-RAWEX campaign. Atmos Chem Phys 18:17669-17685. https://doi.org/10.5194/acp18-17669-2018

Viana M, Rivas I, Reche C, Fonseca AS, Pérez N, Querol X, Alastuey A, Álvarez-Pedrerol M, Sunyer J (2015) Field comparison of portable and stationary instruments for outdoor urban air exposure assessments. Atmos Environ 123:220-228. https://doi.org/10.1016/j. atmosenv.2015.10.076

Virkkula A, Makela T, Hillamo R, Yli-Tuomi T, Hirsikko A, Hameri K, Koponen IK (2007) A simple procedure for correcting loading effects of aethalometer data. J Air Waste Manage Assoc 57:12141222. https://doi.org/10.3155/1047-3289.57.10.1214

Wang YQ (2014) MeteoInfo: GIS software for meteorological data visualization and analysis. Meteorol Appl 21:360-368. https://doi.org/ 10.1002/met. 1345

Wang F, Li Z, Ren X, Jiang Q, He H, Dickerson RR, Dong X, Lv F (2018a) Vertical distributions of aerosol optical properties during 
the spring 2016 ARIAs airborne campaign in the North China Plain. Atmos Chem Phys 18:8995-9010. https://doi.org/10.5194/acp-188995-2018

Wang Q, Sun Y, Xu W, Du W, Zhou L, Tang G, Chen C, Cheng X, Zhao X, Ji D, Han T, Wang Z, Li J, Wang Z (2018b) Vertically resolved characteristics of air pollution during two severe winter haze episodes in urban Beijing, China. Atmos Chem Phys 18:2495-2509. https://doi.org/10.5194/acp-18-2495-2018

Wendisch M, Hellmuth O, Ansmann A, Heintzenberg J, Engelmann R, Althausen D, Eichler H, Wuller D, Hu M, Zhang Y, Mao J (2008) Radiative and dynamic effects of absorbing aerosol particles over the Pearl River Delta, China. Atmos Environ 42:6405-6416. https:// doi.org/10.1016/j.atmosenv.2008.02.033

Willis MD, Bozem H, Kunkel D, Lee AKY, Schulz H, Burkart J, Aliabadi AA, Herber AB, Leaitch WR, Abbatt JPD (2019) Aircraft-based measurements of High Arctic springtime aerosol show evidence for vertically varying sources, transport and composition. Atmos Chem Phys 19:57-76. https://doi.org/10.5194/acp-19-57-2019

Wu C, Yu JZ (2018) Evaluation of linear regression techniques for atmospheric applications: the importance of appropriate weighting. Atmos Meas Tech 11:1233-1250. https://doi.org/10.5194/amt-111233-2018

Wu D, Mao JT, Deng XJ, Tie XX, Zhang YH, Zeng LM, Li F, Tan HB, Bi XY, Huang XY, Chen J, Deng T (2009) Black carbon aerosols and their radiative properties in the Pearl River Delta region. Sci China Ser D 52:1152-1163. https://doi.org/10.1007/s11430-009-0115-y

Wu Y, Zhang R, Pu Y, Zhang L, Ho K, Fu C-B (2012) Aerosol optical properties observed at a semi-arid rural site in northeastern China. Aerosol Air Qual Res 12:503-514

Wu H, Zhang Y-F, Han S-Q, Wu J-H, Bi X-H, Shi G-L, Wang J, Yao Q, Cai Z-Y, Liu J-L, Feng Y-C (2015) Vertical characteristics of PM2.5 during the heating season in Tianjin, China. Sci.Total.Environ. 523: 152-160. https://doi.org/10.1016/j.scitotenv.2015.03.119

Wu C, Wu D, Yu JZ (2018) Quantifying black carbon light absorption enhancement with a novel statistical approach. Atmos Chem Phys 18:289-309. https://doi.org/10.5194/acp-18-289-2018

Wu C, Wu D, Sun JY, Li YJ, Li M, Zhu S, Qiao L, Huang D, Deng T, Sun T, Yang W, Cheng P, Zhou Z (2020) Field evaluation of a multiplewavelength micro Aethalometer, in preperation
Xie C, Xu W, Wang J, Wang Q, Liu D, Tang G, Chen P, Du W, Zhao J, Zhang Y, Zhou W, Han T, Bian Q, Li J, Fu P, Wang Z, Ge X, Allan J, Coe H, Sun Y (2019) Vertical characterization of aerosol optical properties and brown carbon in winter in urban Beijing, China. Atmos Chem Phys 19:165-179. https://doi.org/10.5194/acp-19165-2019

Zarzycki CM, Bond TC (2010) How much can the vertical distribution of black carbon affect its global direct radiative forcing? Geophys Res Lett:37. https://doi.org/10.1029/2010GL044555

Zhang XY, Wang YQ, Zhang XC, Guo W, Niu T, Gong SL, Yin Y, Zhao P, Jin JL, Yu M (2008) Aerosol monitoring at multiple locations in China: contributions of EC and dust to aerosol light absorption. Tellus B 60:647-656. https://doi.org/10.1111/j.1600-0889.2008. 00359.x

Zhang XY, Wang YQ, Niu T, Zhang XC, Gong SL, Zhang YM, Sun JY (2012) Atmospheric aerosol compositions in China: spatial/temporal variability, chemical signature, regional haze distribution and comparisons with global aerosols. Atmos Chem Phys 12:779-799. https://doi.org/10.5194/acp-12-779-2012

Zhou W, Wang Q, Zhao X, Xu W, Chen C, Du W, Zhao J, Canonaco F, Prévôt ASH, Fu P, Wang Z, Worsnop DR, Sun Y (2018) Characterization and source apportionment of organic aerosol at $260 \mathrm{~m}$ on a meteorological tower in Beijing, China. Atmos Chem Phys 18:3951-3968. https://doi.org/10.5194/acp-18-3951-2018

Zhuang BL, Wang TJ, Liu J, Li S, Xie M, Yang XQ, Fu CB, Sun JN, Yin CQ, Liao JB, Zhu JL, Zhang Y (2014) Continuous measurement of black carbon aerosol in urban Nanjing of Yangtze River Delta, China. Atmos Environ 89:415-424. https://doi.org/10.1016/j. atmosenv.2014.02.052

Zhuang BL, Wang TJ, Liu J, Ma Y, Yin CQ, Li S, Xie M, Han Y, Zhu JL, Yang XQ, Fu CB (2015) Absorption coefficient of urban aerosol in Nanjing, West Yangtze River Delta, China. Atmos Chem Phys 15: 13633-13646. https://doi.org/10.5194/acp-15-13633-2015

Publisher's note Springer Nature remains neutral with regard to jurisdictional claims in published maps and institutional affiliations. 